\title{
STUDI KUALITAS AIR TANAH DANGKAL DAN PENDAPAT MASYARAKAT SEKITAR TEMPAT PEMROSESAN AKHIR SAMPAH SUWUNG KECAMATAN DENPASAR SELATAN, KOTA DENPASAR
}

\author{
I. W. Agus Eka Subrata Jaya ${ }^{\left.1^{*}\right)}$ I Wayan Suarna ${ }^{2)}$ dan I Wayan Redi Aryanta ${ }^{1)}$ \\ ${ }^{1)}$ Program Magister Ilmu Lingkungan Universitas Udayana \\ ${ }^{2)}$ Fakultas Peternakan Universitas Udayana \\ ${ }^{*}$ Email: goes_jee@yahoo.com
}

\begin{abstract}
Research has been conducted to determine the quality of shallow groundwater (dug-wells and shallow bore-wells) and the local communities opinions around the landfill Suwung. The method of determining the station was done by purposive sampling, where the station sampling was determined by selecting a place which was expected to represent the whole area.Water sampling of dug-wells was conducted by using a water sampler and the shallow bore-wells using a 2-liter bottle. Data was analyzed by descriptive comparative referenceto class I water quality of the Bali Governor Regulation No. 8 of 2007 . The public opinion data was obtained by using aquesioner filled by respondents who have and use wells and shallow bore wells for their daily needsand it was analyzed by using frequency distribution tables. The results showed that the quality of shallow groundwater (dug-wells and shallow bore-wells) did not meet water quality standards in accordance with the rules of the class defined in the Governor of Bali Regulation No. 8 of 2007. The water pollution index (PI) of dug-wells at a distance of 1-400 meters was in hearily polluted category, while water fromshallow bore-wells drilled at a distance of 1-200 meters was in the category of hearily polluted and at a distance of 201-400 meters was in the category of medium polluted.There was an increasing range of groundwater quality deterioration in 1997, 2008 and 2014. In 1997, contaminated shallow groundwater has occured at a distance of 80 meters, while in 2008, the pollution has occurred up to a distance of 375 meters and in the year of 2014 the contamination occurred from a distance of 1 meter to 400 meters. The average of score Pollution Index (PI) of Water wells in the year of 2008 amounted to 14.55, while in 2014 up to 15.44. It is estimated that the water quality of dug-wells and bore-wells will meet the quality standards in accordance with the value of the pollution index at a distance of over 5000 meters and 750 meters of the Suwung landfill waste.Most of the respondents who live in the vicinity Suwung landfill waste tend to give an opinion that the shallow groundwater (dug-wells and shallow bore-wells) has decreased quality as drinking water. Approximately $75 \%$ of respondents thought that the well water in their environment has been reduced in quality.
\end{abstract}

Keywords: Shallow groundwater; landfill waste of Suwung;pollution index; groundwater quality

\section{PENDAHULUAN}

Pulau Bali dengan luas kurang lebih 5.636,66 $\mathrm{km}^{2}$ dengan jumlah penduduk yang mencapai 3.890.757 jiwa sangat rentan terhadap berbagai dampak negatif dari pembangunan berskala nasional dan regional (Badan Pusat Statistik Provinsi Bali, 2013). Perkembangan penduduk Bali, khususnya di Kota besar seperti Denpasar dan Kabupaten Badung menyebabkan bertambahnya jumlah produksi dan konsumsi barang, sehingga berdampak pada timbulnya berbagai macam buangan (sampah) yang dihasilkan (Widyatmoko dan Sintorini, 2002).Menurut Effendi (2003), pencemaran lingkungan oleh sampah maupun limbah dipandang sangat penting untuk dikendalikan karena apabila air yang tercemar oleh zat-zat yang terkandung dalam bahan-bahan buangan (sampah) akan berdampak sangat luas dan meracuni berbagai macam organisme yang mengkonsumsinya.

Dalam mengatasi permasalahan sampah di Bali Khususnya daerah Denpasar dan Badung,
Pemerintah Provinsi Bali menetapkan salah satu wilayah sebagai Tempat Pemrosesan Akhir (TPA) sampah yaitu Tempat Pemrosesan Akhir (TPA) sampah Suwung dengan luas sebesar 32,64 hektar (Dinas Kebersihan dan Pertamanan Kota Denpasar, 2012). Sampai saat ini sistem yang di pakai dalam pengelolaan sampah Di TPA Sampah suwung masih menerepakan sistem open dumping. Menurut Sundra (1997), sistem Open dumping berdampak sangat besar pada kualitas air tanah dangkal disekitarnya, hal ini dikarenakan sampah yang masuk ke TPA ditumpuk secara terbukaakan menghasilkan zat pencemar berupa cairan lindi atau leachate yang dapat meresap ke dalam tanah melalui limpasan air permukaan dan akhirnya dapat mencemari air tanah dangkal.

Air tanah dangkal merupakan air kebutuhan primer bagi masyarakat yang tidak memiliki air ledeng atau PAM dan biasa ditemui berupa sumur gali atau sumur bor dangkal dalam rumah-rumah penduduk, karena lewat inilah pemenuhan air bagi penduduk yang bermukim di sekitar wilayah TPA sampah Suwung 
tersebut tercukupi (Sundra, 1997). Umumnya air tanah dangkal berada hingga kedalaman 20-40 meter. Air tanah dangkal banyak dimanfaatkan masyarakat sebagai sumber air baku dengan membuat sumur gali dan sumur bor dangkal (Sutandi, 2012). Menurut Putra (2012), apabila air sumur tercemar oleh lindi dari TPA sampah Suwung, maka akan terjadi penurunan kualitas air sumur tersebut dan mungkin pula tidak bisa dimanfaatkan lagi sebagaimana mestinya dan bisa berdampak pada kesehatan masyarakatnya.

Terkait dengan hal ini, maka dilakukan penelitian kualitas air sumur gali dan sumur bor dangkal dan penduduk yang bermukim dekat dengan wilayah Tempat Pemrosesan Akhir (TPA) sampah Suwung dan masih dalam wilayah Banjar Pesanggaran, Kelurahan Pedungan, Kecamatan Denpasar Selatan. Tujuan dari penelitian ini adalah untuk mengetahui kualitas (fisik, kimia dan mikrobiologi) air tanah dangkal di sekitar TPA Sampah Suwung, mengetahui perbedaan kualitas air sumur gali dan sumur bor dangkal penduduk di sekitar TPA Sampah Suwung, mengetahui pendapat masyarakat yang bermukim di sekitar TPA Sampah mengenai kualitas air sumur gali dan sumur bor dangkal, dan mengetahui kecenderungan pencemaran air tanah dangkal di sekitar TPA sampah Suwung tahun 1997, tahun 2008, dan tahun 2014.

\section{METODOLOGI}

Pengambilan sampel air dilakukan pada bulan Maret 2014. Penentuan lokasi sampling air sumur dilakukan dengan Metode Purposive sampling. Metode Purposive Sampling merupakan salah satu metode teknik sampling yang digunakan untuk menentukan bahwa lokasi pengambilan sampel bisa menggambarkan karakteristik keseluruhan daerah tersebut (Sundra,1997). Penentuan lokasi pengambilan sampel ini terdiri dari dua tahap yaitu tahap pertama pengelompokan jarak lokasi sumur penduduk terhadap TPA sampah Suwung dan tahap kedua penentuan sampel sumur penduduk yang ada di daerah tersebut.

Air tanah dangkal yang diambil berupa sampel air sumur gali dan sumur bordangkal warga yang bermukim disekitar areal TPA Sampah Suwung (Sundra, 1997). sampel tersebut diambil pada 4 lokasi sampel (stasiun) pada jarak 1-100 m (S1), 101-200 m (S2), 201-300 m (S3), dan 301-400 m (S4). Masingmasing stasiun diambil secara acak lima sampel sumur gali dan lima sampel sumur bor dangkalpenduduk yang mewakili seluruh jarak dan kedalaman sumur disetiap lokasi. Kelima sampel sumur gali dan sumur bor dangkalmasing-masing dikomposit menjadi satu.

Cara pengambilan sampel air sumur gali pada sumur penduduk dilakukan dengan sampel diambil dalam dasar sumur setelah dilakukan pengadukan selama 2-3 menit,kemudian sampel diambil dengan menggunakan water sampler. Pengambilan air sumur bor dangkaldengan pompa mesin atau tangan dilakukan dengan cara sampel diambil dari mulut pompa yang dilakukan setelah air dibuang selama lebih kurang 5 menit (Effendi, 2003).

Analisis fisik, kimia dan mikrobiologi dilakukan secara insitu dan laboratorium. Hasil yang diperoleh dari analisis dibandingkan secara deskriptif komparatif dan menghitung Indeks Pencemaran (IP). Standar kualitas air ditentukan menurut Peraturan Gubernur Bali Nomor 8 Tahun 2007 untuk baku mutu air Kelas I. Penentuan status mutu air tanah dangkal menggunakan metode indeks pencemaran menurut Keputusan Menteri Negara Lingkungan Hidup Nomor 115 Tahun 2003.

Data kualitas air sumur dihitung Indeks Pencemaran (IP) menggunakan persamaan:

$\mathrm{IP}_{\mathrm{j}}=\sqrt{\frac{\left(\mathrm{C}_{\mathrm{i}} / \mathrm{L}_{\mathrm{ij}}\right)_{\mathrm{M}}^{2}+\left(\mathrm{C}_{\mathrm{i}} / \mathrm{L}_{\mathrm{ij}}\right)_{\mathrm{R}}^{2}}{2}}$

Keterangan notasi :

$\mathrm{L}_{\mathrm{ij}} \quad=\quad$ Konsentrasi parameter kualitas air yang dicantumkan dalam baku peruntukan air

$\mathrm{C}_{\mathrm{ij}} \quad=$ Konsentrasi parameter kualitas air yang diperoleh dari hasil analisis

$\mathrm{IP}_{\mathrm{i}} \quad=$ Indeks pencemaran bagi peruntukan

$\left(\mathrm{C}_{\mathrm{i}} / \mathrm{L}_{\mathrm{ij}}\right)_{\mathrm{M}}=$ Nilai dari perhitungan $\mathrm{C}_{\mathrm{i}} / \mathrm{L}_{\mathrm{ij}}$ maksimum $\left.\left(\mathrm{C}_{\mathrm{i}} / \mathrm{L}_{\mathrm{ij}}\right)_{\mathrm{R}}\right)_{\mathrm{N}}=$ Nilai dari perhitungan $\mathrm{C}_{\mathrm{i}} / \mathrm{L}_{\mathrm{ij}}$ rata-rata

Evaluasi terhadap nilai IP adalah :

$0 \leq \mathrm{IP} \leq 1,0 \rightarrow$ memenuhi baku mutu (kondisi baik)

$1,0<\mathrm{IP} \leq 5,0 \rightarrow$ cemar ringan

$5,0<\mathrm{IP}_{\mathrm{i}} \leq 10 \rightarrow$ cemar sedang

$\mathrm{IP}>10 \rightarrow$ cemar berat

(Kementerian Lingkungan Hidup, 2003).

Pengumpulan data pendapat masyarakat terhadap kualitas air tanah dangkal (sumur gali dan sumur bordangkal) di sekitar TPA sampah Suwung dilakukan dengan menggunakan kuesioner. Metode pengambilan sampel ditentukan dengan purposive sampling, yaitu penduduk disekitar wilayah TPA sampah Suwung yang memiliki dan menggunakan air sumur gali dan sumur bor dangkal(Sugiyono, 2013).

\section{HASIL DAN PEMBAHASAN}

Kualitas air tanah dangkal (sumur gali dan sumur bordangkal) dalam tiap-tiap jarak pengukuran memiliki kualitas yang berbeda-beda. Semakin dekat jarak sumur dengan TPA Sampah Suwung maka kualitas air tanah dangkal (air sumur gali dan sumur bordangkal) yang terukur semakin menurun. Hasil pengukuran parameter fisik, kimia dan mikrobiologi menghasilkan data bahwa kualitas air sumur bor cenderung lebih baik dibandingkan dengan sumur gali. Hal ini ditandai dengan polutan yang terukur pada air sumur bor lebih sedikit dibandingkan dengan sumur gali. 
Tabel 1. Hasil Analisis Pengukuran Sampel Air Sumur Gali Penduduk Di Sekitar Wilayah TPA Sampah Suwung.

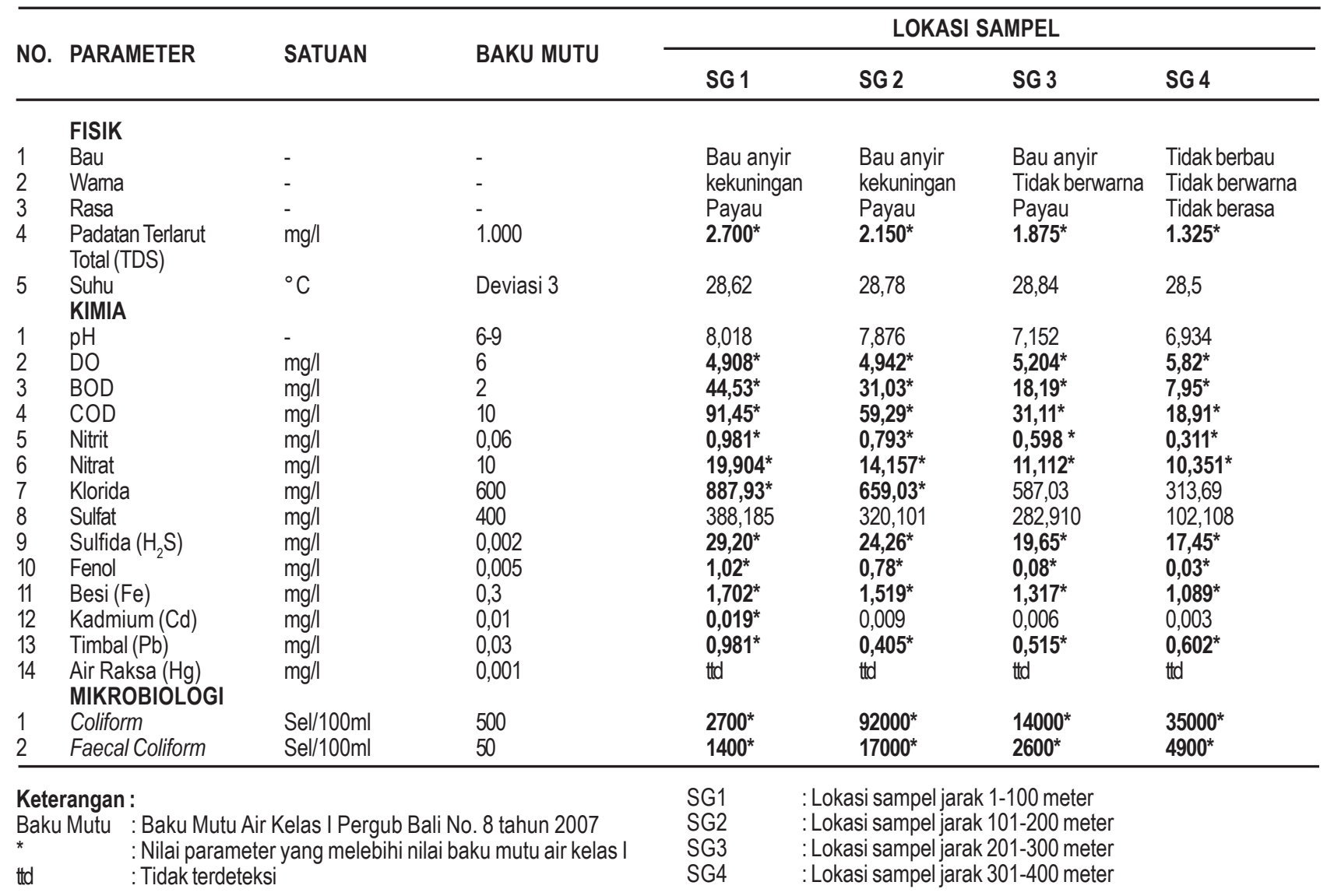

Tabel 2.Hasil Analisis Pengukuran Sampel Air Sumur Bor Dangkal Penduduk Di Sekitar Wilayah TPA Sampah Suwung.

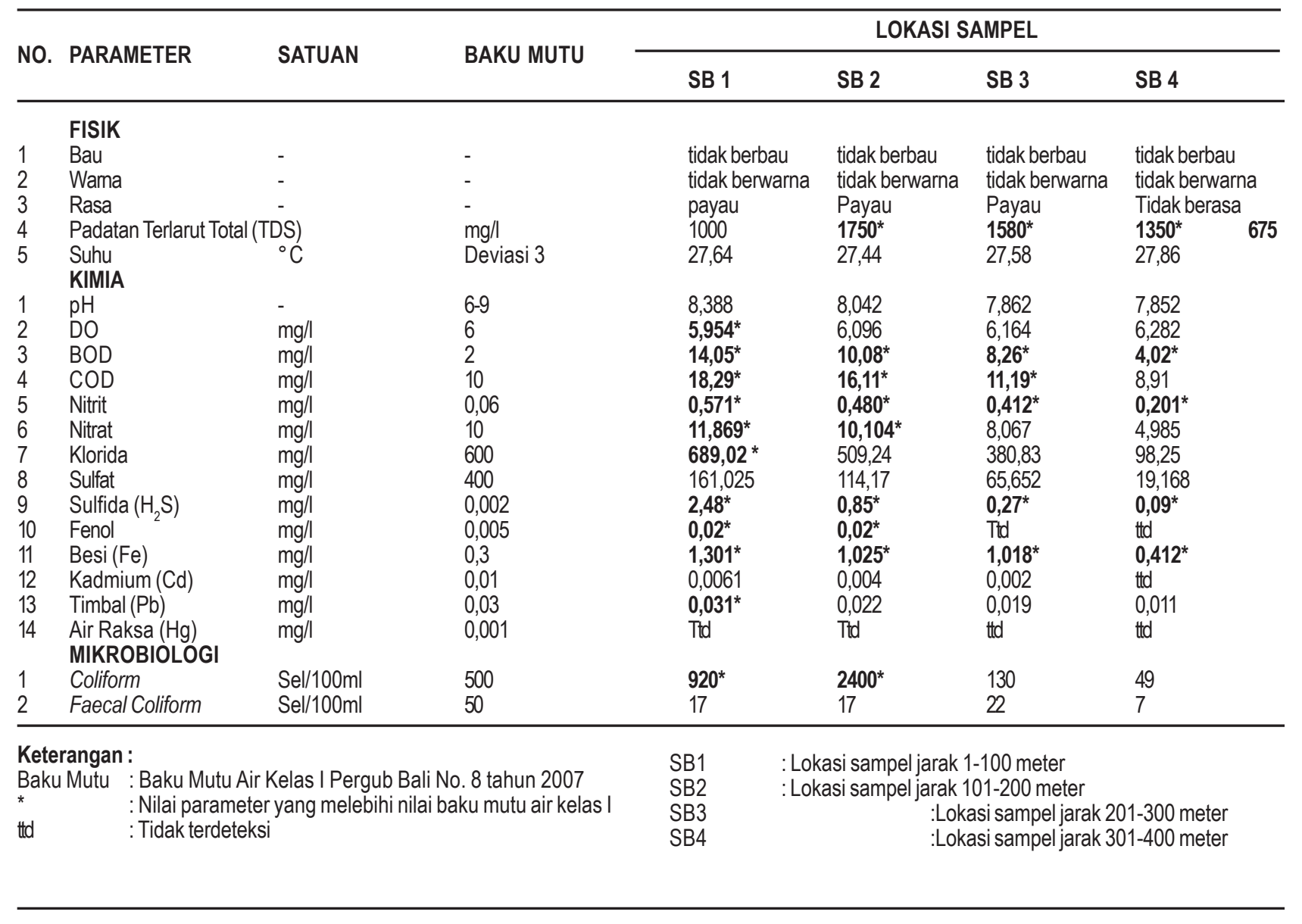


Tabel 3.Hasil Pengukuran Rata-Rata Sampel Air Sumur Gali dan Sumur BorDangkal PendudukDi Sekitar Wilayah TPA Sampah Suwung

\begin{tabular}{|c|c|c|c|c|c|}
\hline \multirow{2}{*}{ NO. } & \multirow{2}{*}{ PARAMETER } & \multirow{2}{*}{ SATUAN } & \multirow{2}{*}{ BAKU MUTU } & \multicolumn{2}{|c|}{ RATA-RATA PENGUKURAN SAMPEL AIR } \\
\hline & & & & SUMUR GALI & SUMUR BOR \\
\hline & FISIK & & & & \\
\hline 1 & Padatan Terlarut total & $\mathrm{mg} / \mathrm{l}$ & 1000 & $2012,5^{\star}$ & $1271^{*}$ \\
\hline 2 & $\begin{array}{l}\text { Suhu } \\
\text { KIMIA }\end{array}$ & ${ }^{\circ} \mathrm{C}$ & Deviasi 3 & 28,685 & 27,63 \\
\hline 1 & $\mathrm{pH}$ & - & 6 sampai 9 & 7,495 & 8,036 \\
\hline 2 & DO & $\mathrm{mg} / \mathrm{l}$ & 6 & $5,224^{*}$ & 6,124 \\
\hline 3 & BOD & $\mathrm{mg} / \mathrm{l}$ & 2 & $25,425^{\star}$ & $9,1025^{*}$ \\
\hline 4 & COD & $\mathrm{mg} / \mathrm{l}$ & 10 & $50,19^{*}$ & $13,625^{\star}$ \\
\hline 5 & Nitrit & $\mathrm{mg} / \mathrm{l}$ & 0,06 & $0,67075^{\star}$ & $0,416^{*}$ \\
\hline 6 & Nitrat & $\mathrm{mg} / \mathrm{l}$ & 10 & $13,881^{*}$ & 8,756 \\
\hline 7 & Klorida & $\mathrm{mg} / \mathrm{l}$ & 600 & $611,92^{*}$ & 419,335 \\
\hline 8 & Sulfat & $\mathrm{mg} / \mathrm{l}$ & 400 & 273,326 & 81,948 \\
\hline 9 & Sulfida & $\mathrm{mg} / \mathrm{l}$ & 0,002 & $22,64^{*}$ & 0,9225 \\
\hline 10 & Fenol & $\mathrm{mg} / \mathrm{l}$ & 0,005 & $0,4775^{\star}$ & $0,010^{*}$ \\
\hline 11 & Besi (Fe) & $\mathrm{mg} / \mathrm{l}$ & 0,3 & $1,407^{*}$ & $0,939^{*}$ \\
\hline 12 & Kadmium (Cd) & $\mathrm{mg} / \mathrm{l}$ & 0,01 & 0,0092 & 0,003 \\
\hline 13 & Timbal $(\mathrm{Pb})$ & $\mathrm{mg} / \mathrm{l}$ & 0,03 & $0,62575^{\star}$ & $0,031^{*}$ \\
\hline 14 & $\begin{array}{l}\text { Air Raksa (Hg) } \\
\text { MIKROBIOLOGI }\end{array}$ & $\mathrm{mg} / \mathrm{l}$ & 0,001 & ttd & ttd \\
\hline 1 & Coliform & $\mathrm{Sel} / 100 \mathrm{ml}$ & 500 & $28840^{*}$ & $800^{*}$ \\
\hline 2 & Faecal Coliform & $\mathrm{Sel} / 100 \mathrm{ml}$ & 50 & $6475^{*}$ & 16 \\
\hline
\end{tabular}

Keterangan :

Baku Mutu : Baku Mutu Air Kelas I Peraturan Gubernur Bali Nomor 8 Tahun 2007

- Nilai parameter yang melebihi nilai baku mutu air kelas I Peraturan Gubernur Bali Nomor 8 Tahun 2007

\section{PEMBAHASAN}

Hasil analisis data didapatkan bahwa kualitas air sumur gali dan sumur bor dangkalbelum memenuhi baku mutu air kelas satu sesuai dengan peraturan Gubernur Bali Nomor 8 tahun 2007 yaitu sebagai bahan baku air minum. Terdapat 13 parameter yang telah melampaui baku mutu air kelas satu pada air sumur gali (Tabel 3) yaitu : padatan terlarut total, oksigen terlarut (DO), kebutuhan oksigen biologi (BOD), kebutuhan oksigen kimiawi (COD), nitrit, nitrat, klorida, sulfida, fenol, besi, timbal, coliform, dan faecal coliform. Pada air sumur bor dangkalterdapat terdapat 8 parameter yang telah melampaui baku mutu air kelas satu (Tabel 3) yaitu : padatan terlarut total, kebutuhan oksigen biologi (BOD), kebutuhan oksigen kimiawi (COD), nitrit, sulfida, fenol, besi dan coliform. Penurunan kualitas air sumur gali dan sumur bor dangkalpenduduk yang ada di sekitar TPA Sampah Suwung dapat terkait erat dengan adanya sumber pencemaran yang besar yaitu TPA Sampah Suwung. Tercemarnya air tanah dangkal di sekitar wilayah TPA Sampah Suwung baik pada air sumur gali maupun sumur bor dangkal bisa diakibatkan dari rembesan lindi dari TPA Sampah Suwung. Lindi merupakan cairan yang mengandung bahan-bahan organik maupun anorganik, berasal dari dekomposisi sampah dan bersifat toksik bagi lingkungan (Putra, 2012). Air tanah yang tercemar oleh air lindi, kecenderungan polutan yang terkandung dalam air lindi akan berada dan tetap ada pada air tanah, dikarenakan terbatasnya oksigen terlarut untuk proses dekomposisi, sehingga menyebabkan air tanah tidak sesuai lagi untuk untuk peruntukkannya (Ehrig, 1993 dalam Munawar 2011).

Indeks pencemaran (IP) air sumur gali menunjukkan bahwa dari stasiun 1 (S1) yang terdekat dengan TPA Sampah Suwung sampai Stasiun 4 (S4) jarak terjauh dari TPA Sampah Suwung memiliki nilai IP pada kisaran 15,90-14,95 dan evaluasi nilai IP tergolong cemar berat. Nilai indeks pencemaran air sumur bor dangkalberkisar 11,80-6,59. Evaluasi nilai IP dapat dibagi menjadi dua bagian yaitu pada stasiun 1 dan 2 dikategorikan cemar berat, sedangkan stasiun 3 dan 4 dikategorikan kedalam cemar sedang. Dapat dikatakan bahwa kualitas air sumur bor semakin membaik dari Stasiun S3 hingga S4 walaupun dalam evaluasi nilai IP dalam kualitas cemar sedang(Kementerian Negara Lingkungan Hidup Republik Indonesia, 2003).

Rata-rata nilai evaluasi indeks pencemaran (IP) untuk air sumur gali sebesar 15,44 dan dikategorikan cemar berat sedangkan untuk air sumur bor dangkalnilai IP sebesar 9,23 masuk dalam kategori cemar sedang. Hasil pengukuran indeks pencemaran air sumur gali dan sumur bor penduduk di sekitar TPA Sampah Suwung tersaji pada tabel 4 (Kementerian Negara Lingkungan Hidup Republik Indonesia, 2003).

Walaupun air tanah dangkal baik itu sumur gali dan sumur bor dangkal di sekitar TPA Sampah Suwung telah tercemar, akan tetapi terdapat kecenderungan penurunan konsentrasi zat pencemar. Hal ini dapat dibuktikan dari hasil pengukuran 
Tabel 4.Hasil Pengukuran Indek Pencemaran (IP) Air Sumur Gali dan Sumur Bor Penduduk Di Sekitar TPA Sampah Suwung.

\begin{tabular}{lllll}
\hline \multirow{2}{*}{ Jarak Sumur Dari TPA $(\mathrm{m})$} & \multicolumn{2}{c}{ Air Sumur Gali } & \multicolumn{2}{c}{ Air Sumur Bor } \\
\cline { 2 - 5 } & IP & Kategori & IP & Kategori \\
\hline $1-100(\mathrm{~S} 1)$ & 15,90 & Cemar berat & 11,80 & Cemar berat \\
$101-200(\mathrm{~S} 2)$ & 15,73 & Cemar berat & 10,17 & Cemar berat \\
$201-300(\mathrm{~S} 3)$ & 15,17 & Cemar berat & 8,33 & Cemar sedang \\
$301-400(\mathrm{~S} 4)$ & 14,95 & Cemar berat & 6,59 & Cemar sedang \\
& & Cemar berat & $\mathbf{9 , 2 3}$ & Cemar sedang \\
\hline
\end{tabular}

parameter fisik, kimia, mikrobiologi dan indeks pencemaran yang sebagian besar nilainya semakin menurun dari stasiun 1 (S1) jarak yang terdekat dengan TPA Sampah Suwung hingga stasiun 4 (S4) jarak terjauh dari TPA Sampah Suwung. Dapat diasumsikan bahwa faktor jarak sangat berperan dalam masuknya polutan ke dalam sumur-sumur penduduk.Semakin jauh lokasi TPA Sampah Suwung dari lokasi sumur-sumur penduduk maka semakin rendah polutan yang masuk kedalam air sumur gali dan sumur bordangkal. Jarak yang semakin jauh dari sumber pencemar dan kedalaman air dari permukaan tanah menyebabkan penetrasi bahan pencemar ke dalam air tanah dangkal semakin sedikit (Pujiati dan Pebriyanti, 2010).

Terdapat perbedaan kualitas air tanah dangkalpada jarak yang berbeda dimana kecenderungan kualitas air sumur bor dangkaljauh lebih baik dibandingkan dengan air sumur gali. Sedikitnya zat polutan yang masuk ke dalam air sumur bor dangkaldapat terkait erat dengan jarak kedalaman air sumur bor dari permukaan tanah. Umumnya polutan bersifat cair yang terdapat di permukaan tanah, dengan bantuan air permukaan dan gaya gravitasi akan terinfiltrasi masuk kedalam pori-pori tanah sehingga air tanah dibagian atas atau yang terdekat dengan sumber polutan terlebih dahulu mengalami kondisi pencemaran (Apparo, 1997 dalam Putra, 2012). Ketika polutan tersebut terinfiltrasi semakin jauh ke dalam tanah maka akan terjadi pengurangan jumlah polutan yang masuk ke dalam lapisan tanah paling dalam yang diakibatkan oleh beberapa faktor seperti tekstur tanah, bahan penyusun tanah, jenis tanah dan lain sebagainya (Notodarmojo, 2005).

Sebagian besar masyarakat yang bermukim di sekitar TPA Sampah Suwung cenderung memberikan pendapat bahwa air tanah dangkal (sumur gali dan sumur bordangkal) yang ada telah mengalami penurunan kualitas dan pencemaran. Hal ini dapat dilihat dari jawaban responden dalam kuesioner yang telah diberikan dimana sekitar 75\% responden berpendapat bahwa air sumur dilingkunganya telah menurun kualitasnya. Sebanyak 72,5\% responden berpendapat setuju bahwa
TPA sampah Suwung mempengaruhi kualitas air sumur dilingkungannya. Secara keseluruhan responden memberikan pendapat bahwa air sumur gali dilingkungannya tidak layak dipakai sebagai air minum dikarenakan rasa yang aneh, berbau seperti air selokan dan berwarna keruh sedangkan 70\% responden berpendapat air sumur bordangkal juga tidak layak dipakai sebagai air minum dikarenakan rasa yang sudah asin. Dari segi perbandingan kualitas antara air sumur gali dengan sumur bor, sebanyak 90\% responden berpendapat kualitas air sumur bor dangkallebih baik dibandingkan dengan air sumur gali.Sebanyak $45 \%$ responden memberikan keluhan kesehatan dalam pemakaian air sumur terutama untuk mandi yaitu keluhan gatal-gatal dan bintik-bintik merah dikulit, sedangkan 53\% responden tidak mendapatkan keluhan apapun terkait pemakaian air sumur untuk kegiatan rumah tangga. Sedikitnya keluhan terhadap pemakaian air sumur oleh responden kemungkinan disebabkan oleh pengaruh sistem kekebalan tubuh. Sistem imunitas setiap makhluk hidup termasuk manusia berbedabeda tergantung dari dua faktor besar yaitu faktor genetik dan faktor lingkungan. Adaptasi terhadap lingkungan memberikan respon yang baik terhadap pembentukan imunitas, sehingga memiliki kekebalan terhadap suatu penyakit dilingkungan tersebut (Sumantri, 2013).

Kecenderungan terjadi penurunan kualitas air tanah dangkal di sekitar TPA Sampah Suwung dari tahun 1997, 2008, dan tahun 2014. Hal ini dapat dilihat dari perbedaan jarak air tanah dangkal yang tercemar dan indeks pencemaran (PI). Ditahun 1997 air tanah dangkal yang telah tercemar terjadi pada jarak 0-80 meter dari TPA Sampah Suwung sedangkan ditahun 2008 pencemaran telah terjadi hingga jarak 375 meter dan di tahun 2014 pencemaran terjadi dari jarak 1 meter hingga 400 meter. Rata-rata evaluasi nilai Indeks Pencemaran (PI) Air sumur gali di tahun 2008 sebesar 14,55 sedangkan di tahun 2014 naik menjadi sebesar 15,44. $\mathrm{Hal}$ ini membuktikan bahwa terjadi peningkatan beban atau bahan-bahan polutan dari TPA Sampah Suwung yang masuk dan mencemari air tanah dangkal di sekitarnya. 


\section{SIMPULAN DAN SARAN}

\subsection{Simpulan}

1. Semakin jauh jarak sumur dengan TPA Sampah Suwung, kualitas air tanah dangkal semakin membaik. Pengukuran dengan indeks pencemaran, kualitas air sumur gali ada dalam kategori cemar berat, sedangkan air sumur bor pada jarak 1-200 meter ada dalam kategori cemar berat dan jarak 201-400 meter dalam kategori cemar sedang.

2. Terdapat perbedaan antara kualitas air sumur gali dengan sumur bor pada jarak yang berbeda dimana kecenderungan kualitas air sumur bor lebih baik dibandingkan dengan air sumur gali.

3. Kualitas air sumur gali dan sumur bor tidak memenuhi baku mutu air kelas satu sesuai dengan peraturan Gubernur Bali Nomor 8 tahun 2007.

4. Sebagian besar masyarakat yang bermukim di sekitar TPA Sampah Suwung berpendapat bahwa air tanah dangkal (sumur gali dan sumur bor) yang ada telah mengalami penurunan kualitas dan mengalami pencemaran.

5. Terjadi penurunan kualitas air tanah dangkal di sekitar TPA Sampah Suwung yang diperoleh sejak tahun tahun 1997, 2008, dan tahun 2014.

\subsection{Saran}

1. Guna meminimalisir pencemaran air tanah dangkal akibat polutan dari TPA Sampah Suwung, seluruh instansi atau pihak terkait yang berwenang dan bertanggungjawab terhadap pengelolaan TPA Sampah Suwungdisarankan melakukan kajian lebih dalam dan perubahan sistem pengolahan sampah dari sistem open dumping beralih ke sistem sanitary landfill atau sistem control landfill.

2. Untuk masyarakat umum dan khsususnya yang bermukim di sekitar areal TPA Sampah Suwung, sebaiknya tidak menggunakan sumber air tanah dangkal di sekitar TPA sebagai konsumsi airbaku air minum sehari-hari.

3. Perlu dilakukan penelitiansecara berkala mengenai kualitas air tanah dangkal di sekitar TPA Sampah Suwung, sehingga nantinya dapat diprogramkan tentang pemetaan daerah mengenai tingkat kualitas air tanah.

4. Perlu dilakukan kajian lebih lanjut mengenai bahan pencemar lindi di TPA Sampah Suwung dan cara untuk mengatasinya, sehingga dampak pencemaran terhadap air tanah dangkal bisa diminimalisir.

\section{DAFTAR PUSTAKA}

Badan Pusat Statistik Provinsi Bali. 2013. Luas Wilayah, Jumlah Rumahtangga, dan Jumlah Penduduk Hasil Registrasi Penduduk Menurut Kabupaten/Kota di Bali Tahun 2011. Available From: URL: http://bali.bps.go.id/ Tabel_detail.php?ed $=604003 \&$ od $=4 \& i d=4$. Diakses tanggal 18 Nopember 2013.

Dinas Kebersihan dan Pertamanan Kota Denpasar. 2012. TPA Suwung. Available From: URL: http:/ /www.denpasarkota.go.id/instansi/file / ?TPA.pdf.Diakses tanggal 20 Nopember 2013.

Effendi, H. 2003. Telaah Kualitas Air Bagi Pengelolaan Sumber Daya dan Lingkungan Perairan. Kanisius. Yogyakarta.

Kementerian Lingkungan Hidup Republik Indonesia. 2003. Keputusan Menteri Negara Lingkungan Hidup Nomor : 115 Tahun 2003 Tentang Pedoman Penentuan Status Mutu Air. Jakarta.

Munawar, A. 2011. Rembesan Air Lindi (Leachate) Dampak Pada Tanaman Pangan. UPN Press. Surabaya.

Notodarmojo, S. 2005. Tanah dan Air Tanah. ITB. Bandung

Pemerintah Provinsi Bali. 2007. Peraturan Gubernur Bali Nomor 8 Tahun 2007 tentang Baku Mutu Lingkungan Hidup dan Kriteria Baku Kerusakan Lingkungan Hidup. Denpasar.

Pujiati, S. R Dan D. W. Pebriyanti. 2010. Pengaruh Jarak Sumur Gali Dengan Septic Tank Terhadap Kandungan Bakteri Coliform Pada Air Sumur Gali(Studi di Kelurahan Citrodiwangsan, Kecamatan Lumajang, Kabupaten Lumajang). Jurnal IKESMA 6 (1) : 25-33.

Putra, I. K. 2012. Identifikasi Arah Rembesan dan Letak Akumulasi Lindi dengan Metode Geolistrik Resistivitas Konfigurasi Wenner-Schlumberger di TPA Temesi Kabupaten Gianyar. Tesis. Program Studi Ilmu Lingkungan. Universitas Udayana. Denpasar.

Sugiyono. 2013. Metode Penelitian Pendidikan Pendekatan Kuantitatif, Kualitatif, dan R \& B. Alfabeta. Bandung.

Sumantri, H. A. 2013. Kesehatan Lingkungan. Kencana Prenada Media Grup. Jakarta.

Sundra, I.K. 1997. Pengaruh Pengelolaan Sampah Terhadap Kualitas Air Sumur Gali di Sekitar Tempat Pembuangan Akhir Sampah Suwung Denpasar Bali. Jurnal Lingkungan Dan Pembangunan 19 (3) : 206-214.

Sutandi, M.C. 2012. Air Tanah. Available from http:/ /repository.maranatha. edu/3914/1/Air\%20 Tanah.pdf. Diakses tanggal 4 Maret 2014.

Widyatmoko, H. dan Sintorini. 2002. Menghindari, Mengolah dan Menyingkirkan Sampah. PT. Dinastindo Adiperkasa Internasional. Jakarta. 